\title{
Estádio Chile, 1973: os dias finais de Víctor Jara, uma vítima da ditadura chilena
}

Chile Stadium, 1973: the final days of Víctor Jara, A VICTIM OF THE CHILEAN DICTATORSHIP

L Viviane Borelli

Professora do Programa de Pós-Graduação em Comunicação da Universidade Federal de Santa Maria. Doutora em Ciências da Comunicação pela Unisinos.

viviborelli10@gmail.com

\section{Maurício Marques Brum}

Mestrando pelo Programa de Pós-Graduação em História da Universidade Federal do Rio Grande do Sul, com financiamento do CNPq. Bacharel em Comunicação Social - Jornalismo pela Universidade Federal de Santa Maria.

mauribrum@gmail.com

Recebido em 25 de abril de 2014. Aprovado em 25 de agosto de 2014

\section{Resumo}

Este artigo descreve o processo de apuração, escrita e edição de uma reportagem investigativa sobre os últimos dias da vida de Víctor Jara, cantor e compositor chileno executado pela ditadura de Augusto Pinochet em setembro de 1973. Em função da escassez de documentos oficiais do período, a reconstituição dos acontecimentos baseou-se fundamentalmente na história oral, seja por meio de fontes primárias, por meio de entrevistas com ex-prisioneiros políticos, ou secundárias, por meio de depoimentos transcritos de pesquisas anteriores.

Palavras-chave: Ditadura militar chilena. História oral. Víctor Jara.

\section{Abstract}

This paper describes the research, writing and editing of an investigative report on the last days of life of Víctor Jara, a Chilean singer and songwriter executed by the dictatorship of Augusto Pinochet in September 1973. Due to the lack of official documents of the period, the reconstruction of the events relied mostly on oral history, whether through primary sources, through interviews with former political prisoners, or secondary sources, through transcribed testimonials from previous researches.

Keywords: Chilean military dictatorship. Oral history. Víctor Jara. 


\section{Introdução: as muitas versões de uma execução}

Na manhã de 16 de setembro de 1973, alguns moradores da comuna de Lo Espejo, no sul de Santiago do Chile, violaram o toque de recolher imposto pela ditadura de Augusto Pinochet, instaurada cinco dias antes, e se aproximaram de uma fileira de seis corpos deixados na rua por militares à paisana. Três foram identificados, e havia alguns rostos familiares. Um deles, apesar de desfigurado, seria reconhecido como o cantor e compositor Víctor Jara, um dos músicos mais conhecidos do país. Notório por suas canções de protesto, que preferia chamar de "revolucionárias", ${ }^{1}$ Jara era filiado ao Partido Comunista e pertencera à linha de frente da coletividade de artistas que apoiou o governo do presidente Salvador Allende, deposto pelo golpe liderado por Pinochet.

A perseguição fez de Víctor Jara um mártir da luta contra a ditadura, quando esta se encontrava ainda em sua fase inicial. Propagaram-se, desde então, versões contraditórias sobre suas horas finais. Fosse como estratégia para causar aversão ao regime ou pelo desconhecimento quanto ao que ocorrera entre as paredes do Estádio Chile, ${ }^{2}$ os relatos dissonantes muitas vezes apontavam para uma mesma sequência de cenas simbólicas. Por décadas, contou-se que Víctor Jara cantou na prisão para provocar os militares e inspirar seus colegas de cárcere; ademais, ele teria tido as mãos (ou dedos, conforme a versão) cortadas, para que não mais tocasse o violão; por fim, teria sido fulminado por uma rajada de metralhadoras, após entoar o refrão de "Venceremos"3 e ser acompanhado em coro pelas arquibancadas lotadas de prisioneiros políticos.

Os relatos não podiam ser questionados facilmente, pela própria natureza da reconstituição: os detidos eram colocados em setores distintos, e os poucos que tiveram contato com Jara nunca o fizeram durante a totalidade do tempo em que passou encarcerado. Sem uma série de entrevistas complementares, era impossível estabelecer com precisão o que efetivamente ocorrera. Além disso, a sequência cronológica dos fatos também se impunha como um desafio para os pesquisadores: mantidos em um recinto fechado, os prisioneiros em geral não possuíam noção do tempo. Tais condições prejudicaram a formação de uma ideia clara do que acontecia além de suas vistas - e de quando isso acontecia. Estima-se que até 7 mil pessoas tenham passado pelo Estádio Chile na semana em que o recinto foi improvisado como prisão após o golpe de 11 de setembro. No entanto,

1 Joan Jara (1998, p. 167).

2 Ginásio localizado na comuna de Estación Central, próximo à antiga Universidade Técnica do Estado (UTE) onde Jara trabalhava e foi detido.

3 Hino da Unidade Popular, coligação do presidente Salvador Allende, composto durante a campanha eleitoral de 1970 por uma comissão de artistas que incluiu o próprio Víctor Jara.

\section{$24 \frac{\text { Comunicação \& Inovação, PPGCOM/USCS }}{\text { v. 16, n. } 30 \text { (23-37) jan-abr } 2015}$}


como escreve Kósichev (1990, p. 241), “as testemunhas contam como e em que condições o viram [Víctor Jara]. Mas ninguém viu o todo. Aí se afirma a lenda". ${ }^{4}$

$\mathrm{Na}$ pesquisa, ${ }^{5}$ buscamos mapear as origens das versões sobre a morte de Víctor Jara, de modo a compreender as implicações na sociedade chilena de sua atuação artística e política, bem como de seu assassinato. Para tanto, recuperamos a evolução e a transformação das narrativas sobre sua morte através do tempo e propusemos possíveis explicações para a persistência de versões que não correspondiam - parcial ou totalmente - aos fatos. Após esse mapeamento documental, discutimos como a história oral nos ajudou na busca por informações pouco claras acerca dos últimos momentos de vida de Jara.

Diante da inexistência ou inacessibilidade de documentos oficiais da época a respeito do que ocorreu no Estádio Chile entre 12 e 16 de setembro de 1973 (quando Jara esteve preso), qualquer trabalho que se proponha a investigar essa rotina da prisão não pode se furtar de utilizar a história oral. Não apenas no que diz respeito às entrevistas, mas também por meio de fontes secundárias (transcrições de depoimentos e entrevistas elaboradas por outros pesquisadores). A história oral constitui-se como essencial para a apuração, escrita e edição de uma reportagem com a profundidade pretendida perante um episódio com estas características. Deste modo, a pesquisa valeu-se de arquivos orais e fontes orais: ${ }^{6}$ cerca de quarenta depoimentos e entrevistas transcritos mantidos no acervo da Fundación Víctor Jara (FVJ), em Santiago, e entrevistas que realizamos com nove testemunhas entre julho e setembro de 2012.

Comparando os materiais consultados com os relatos levantados na pesquisa, buscamos alcançar um nível maior de detalhamento em comparação com as reportagens já existentes sobre o tema. A premissa de permitir que o leitor "visualizasse", por meio da narrativa, os acontecimentos do interior do ginásio, levou-nos a escolher um formato que permitisse a pormenorização no texto - o livro-reportagem. ${ }^{7}$

4 Tradução própria.

5 O artigo faz parte do trabalho final de curso que objetivou reconstituir, em um livro-reportagem, o cotidiano do cárcere de Víctor Jara até sua morte. A obra foi publicada em 2014, sob o título Estádio Chile, 1973: Morte e vida de Víctor Jara, a voz da Revolução Chilena.

6 Danièle Voldman (2006, p. 36) diferencia os arquivos orais das fontes orais estabelecendo que os primeiros são as fontes sonoras gravadas no passado e mantidas para consulta futura em instituições destinadas a tal fim, ao passo que as fontes orais constituem o material colhido por um pesquisador para suprir as necessidades de seu trabalho.

7 Na classificação proposta por Edvaldo Pereira Lima (2004, p. 51-59), qualificamos nossa produção como um "livro-reportagem-história" e não como um "livro-reportagem-denúncia". Embora exista aqui o "propósito investigativo" que o autor diz ser necessário para as obras de denúncia, este termo já não cabe no que diz respeito a Víctor Jara, pois com as investigações judiciais resta pouco a denunciar. 


\section{O caso em questão: evolução das narrativas sobre os últimos dias de Víctor Jara}

Filho de agricultores pobres, Víctor Jara nasceu no interior de Chillán Viejo, região meridional do Chile, em 1932. Ainda na infância, mudou-se para a capital, e aos 23 anos ingressou na Escola de Teatro da Universidade do Chile, onde se graduou como ator e diretor. Ali também iniciou sua militância política, filiando-se ao Partido Comunista. Apesar de atingir renome por seu trabalho relacionado à dramaturgia, Jara passou a dedicar tempo à pesquisa de músicas folclóricas do interior chileno, bem como à composição de temas autorais.

Já na metade da década de 1960, o artista se fizera conhecido do grande público por sua atuação no campo musical - onde também evidenciou suas convicções ideológicas. Com composições de raiz folclórica e letras marcadas por um viés político de esquerda, ajudou a fundar o movimento da Nueva Canción Chilena, cuja característica essencial era apontar "abierta o sutilmente, hacia un cuestionamiento crítico de la sociedad, del orden establecido". (BARRAZA, 1972). Nas letras de Jara e de outros expoentes do movimento, "la dependencia cultural, el subdesarrollo, la marginalidad, la insurgencia, la injusticia social, la sociedad de consumo, encuentran [...] un crítico ángulo expresivo". (Ibid.).

A popularidade atingida com as canções levou-o a optar por uma dedicação total à carreira musical. Tal decisão se deu às vésperas da corrida eleitoral de 1970, na qual Salvador Allende se candidatou à frente da Unidade Popular (UP), uma coligação encabeçada por socialistas e comunistas. Allende venceria o pleito, e seus comícios seriam marcados pela participação de intérpretes da Nueva Canción Chilena, como Víctor Jara. Três anos mais tarde, quando a crise econômica, as pressões políticas, os equívocos estratégicos do governo e a poderosa influência dos Estados Unidos levaram à traumática derrubada de Allende e à violenta perseguição dos membros da UP, esses artistas estiveram entre os milhares de chilenos acossados pelo novo regime. ${ }^{8}$

Víctor Jara foi preso em 12 de setembro, a manhã seguinte ao golpe. Quatro dias após a detenção, seu corpo apareceu em Lo Espejo. Não era uma vítima casual:

8 Ángel Parra, filho de Violeta Parra (considerada a fundadora da Nueva Canción Chilena), também foi preso e, embora tenha escapado da execução, precisou partir para o exílio após libertado. O Quilapayún e o IntiIllimani, dois dos conjuntos mais importantes relacionados ao movimento, excursionavam pela Europa na condição de "embaixadores culturais" do governo Allende quando o golpe estourou. Os dois grupos converteram-se imediatamente em asilados políticos, na França e na Itália, respectivamente. 
Compreendemos a execução de Víctor Jara no Estadio Chile não como a de alguém que estava no "lugar errado na hora errada", mas como propiciadora de verificação do terror pelo "exemplo" aos setores que apoiavam ou se identificavam com as propostas do governo da Unidad Popular (SIMÕES, 2011, p. 269).

Se sua morte servia como exemplo de até onde o governo estava disposto a ir para reprimir os chilenos identificados com a UP, para a militância de esquerda - que começava a lutar contra a ditadura - Víctor Jara tornou-se exemplo por uma via alternativa: como mártir da resistência.

A morte do cantor e compositor foi noticiada pela primeira vez em 21 de setembro de 1973, sem alarde, cinco dias após seu corpo ser encontrado. Foi a única nota sobre a morte em toda a imprensa chilena, dado sintomático da escassez de documentos produzidos na época a respeito do que ocorreu. A notícia saiu no vespertino La Segunda, de Santiago, que descreveu o falecimento em uma nota de seis linhas publicada na última página. Por censura ou colaboracionismo, o texto não indicava as razões do óbito: "Murió el folklorista Víctor Jara. Sus restos fueron enterrados en el Cementerio General el pasado miércoles. Acompañaron el cortejo sus familiares e íntimos amigos, en la más completa reserva. El artista deja una hija de seis años." (LA SEGUNDA, 1973, p. 24). Além de não informar a causa mortis, a nota equivocava-se quanto à data do enterro (miércoles, quarta-feira, dia 19, em vez do dia 18), não mencionava o caráter quase clandestino do serviço fúnebre (assistido somente pela viúva do cantor e dois amigos) e errava a idade de Amanda, filha de Víctor e Joan Jara.

Desde aquela notícia, uma série de trabalhos procurou investigar os dias finais do folclorista executado pela ditadura. O jornalista Camilo Taufic (1974) é o autor da investigação pioneira sobre a morte de Jara, apresentando o caso em uma obra publicada no exílio, na qual se dedicava a reunir relatos da repressão nos primeiros meses de Pinochet no poder. Em seu texto principal, Taufic deu preferência aos depoimentos que considerou mais verossímeis, de acordo com os quais Jara não tivera as mãos cortadas tampouco cantara. Apenas em uma nota de rodapé o autor comenta:

Otra versión recogida en Chile por el autor del libro, en medio del laberinto de relatos contradictorios bajo el terror y la censura imperantes, es que Víctor Jara, con sus dedos cortados, fue obligado a cantar desde el escenario del Estadio Chile. Desafiante y erguido, pese a las torturas, interpretó "Venceremos", himno de la Unidad Popular. Su canto fue interrumpido por una ráfaga de metralleta. Así habría muerto. (TAUFIC, 1974, p. 124). 
Desacreditada pelo jornalista, esta versão ganharia mundo nos anos seguintes. $\mathrm{O}$ texto responsável por difundir tal narrativa, enfatizando as mãos cortadas e a cantoria de "Venceremos", é atribuído ao escritor chileno Miguel Cabezas e foi reproduzido em diferentes coletâneas estrangeiras. A crônica em questão foi publicada pelo português Letria (1974) e redobrou sua capacidade de circulação um ano depois, ao ganhar uma versão em inglês na compilação de textos sobre o golpe chileno organizada nos Estados Unidos por Lowenfels (1975).

A partir da década de 1980, com o abrandamento das censuras do regime, e de forma mais acentuada após o termino da ditadura, diversas testemunhas negariam veementemente esses acontecimentos. Alonso (1984), em reportagem publicada pela revista $L a$ Bicicleta, traz o primeiro depoimento negando que Víctor Jara teria cantado. Mais tarde, o jornalista russo Kósichev (1990), baseando-se em entrevistas e trocas de correspondências com ex-companheiros de cárcere de Jara, também não endossaria as suposições trazidas pela nota de rodapé de Taufic (1974) e popularizadas pelo texto de Cabezas. Ainda assim, a versão segundo a qual Víctor Jara teria tido as mãos cortadas e sido assassinado enquanto cantava permanece forte no imaginário do golpe, a ponto de figurar em obras mais recentes, como a do brasileiro Cannabrava Filho (2003).

A tentativa de criar uma narrativa mais fidedigna sobre os momentos finais do músico ganhou nova guinada quando o golpe estava próximo de seu décimo aniversário. Nessa época, a viúva de Víctor, Joan Jara, dedicou-se a entrevistar testemunhas do cárcere e velhos amigos do casal para escrever uma biografia na qual também buscou contemplar o que teria acontecido no Estádio Chile. O texto de Joan acabou por estabelecer uma narrativa "oficial" do que teria ocorrido com Víctor Jara, tornando-se a versão mais conhecida. Nele, Joan desmentia que seu marido tivera as mãos cortadas - uma vez que ela própria viu o cadáver -, mas, baseando-se nas entrevistas que realizou, sustentou que Víctor teria cantado. Apesar de várias reedições, o livro de Joan Jara nunca chegou a ter seu texto atualizado pelas descobertas feitas após a publicação original de 1983.

As investigações realizadas desde então sempre deparavam com a ausência de material documental sobre o Estádio Chile. Como destacam San Francisco et al. (2010), o Estádio Chile foi utilizado em dois períodos distintos: na primeira semana após o golpe, quando ocorreu a execução de Jara e não havia presença de observadores internacionais no país, sendo este o período de repressão mais sangrento da ditadura, e um segundo momento, no qual o ginásio voltou a ser usado como prisão, a partir de novembro de 1973. É desse primeiro momento que datam as maiores atrocidades e em que os documentos são mais escassos. Os trabalhos que precederam o nosso só puderam atingir níveis gradativamente maiores de conhecimento sobre a realidade daqueles dias a partir de fontes orais. 
Além das obras já citadas, destacam-se, mais recentemente, o documentário $E l$ Derecho de Vivir en Paz, de Carmen Luz Parot (1999), a reportagem de Peña (2003) e o livro de entrevistas elaborado pelos espanhóis Jurado e Morales (2003), no qual o formato de perguntas e respostas é substituído por pequenas crônicas em primeira pessoa, a partir dos depoimentos de amigos, familiares e colegas do músico. Além de aprofundar o conhecimento sobre os fatos ocorridos no interior do Estádio Chile, esses trabalhos ajudaram a reconstituir os acontecimentos prévios ao encarceramento no ginásio, quando Víctor Jara e centenas de professores, estudantes e funcionários foram mantidos sob cerco militar no campus da Universidade Técnica do Estado (UTE), desde a manhã de 11 de setembro até a alvorada seguinte, quando foram transferidos.

Apenas no século XXI, com o avanço das investigações judiciais, entraram em cena também os depoimentos dos antigos verdugos: embora os oficiais militares sempre tenham guardado silêncio, os antigos soldados-rasos, quando intimados pela Justiça a se manifestar, passaram a preencher os vazios das narrativas existentes com relatos sobre outros momentos e espaços da prisão. Cuevas (2009) foi a primeira a escrever com base nesses testemunhos, que trouxeram à luz os acontecimentos de um local de onde nenhum prisioneiro saiu com vida: o vestiário onde, longe dos olhos de outros detidos, Víctor Jara foi executado.

\section{Novas perguntas para velhas lacunas: a história oral}

A entrevista é indispensável na construção de um texto jornalístico e essa condição se acentua quando tratamos de uma reportagem de caráter investigativo sobre um tema com material documental limitado. Sherwood (1981, p. 20) constatava que "grande parte das matérias de jornais e revistas e das notícias transmitidas por televisão e rádio é baseada no que fez ou declarou alguma autoridade ou pessoa de prestígio". Com o passar do tempo, o que se modificou foram as características das fontes consultadas, abrindo-se espaço de forma gradual a fontes avaliadas como de "menor prestígio". Em uma obra investigativa, isso é premente, e no caso de Víctor Jara é muito fácil de constatar: foram antigos prisioneiros e soldados subalternos os autores dos principais relatos usados em todas as reconstituições.

Bloch (2001) diz que os documentos são "vestígios", e que o passado, portanto, não é um dado rígido ou inalterável: é antes uma estrutura em progresso constante, elaborada e reelaborada conforme novos dados e interpretações se tornam acessíveis aos pesquisadores. $\mathrm{O}$ autor argumenta que os documentos escritos eram tratados com demasiada inocência: contrariando a ideia de que a fonte escrita é inerentemente confiável, o autor 
recorda que grande parte das fontes não se preservam para consulta futura de forma inocente ou acidental, sendo constituídas e conservadas sempre de acordo com uma intenção.

Desde Bloch (2001), a discutível confiabilidade dos documentos escritos parece já ter se tornado ponto pacífico. Se a fonte oral é criticada, o documento escrito também não pode ser encarado como livre de subjetivação. Com efeito, o estigma criado no passado em torno da utilização do método da história oral talvez torne os pesquisadores que se valem desse tipo de entrevistas ainda mais cuidadosos em relação a suas fontes do que aqueles que apenas manuseiam material escrito. Essa ideia é defendida por Thompson (1992), através da demonstração de que, após séculos de escrita da história nos quais o uso de relatos orais foi basilar, apenas a partir da metade final do século XIX esse tipo de fonte passa a sofrer críticas crescentes. Nesse momento, com influências positivistas, um grande número de pesquisadores passa a priorizar documentos escritos, acreditando atingir assim um grau maior de "objetividade", em busca de um status de "ciência" para suas atividades.

Embora o uso da metodologia da história oral exija um cuidado distinto daquele que se toma com documentos escritos - os esquecimentos, as quebras narrativas e a compactação de períodos distintos em uma única memória são problemas próprios da história oral -, ambos passam por seus próprios processos de subjetivação e precisam ser encarados com a devida margem crítica. De qualquer modo, não há razão para acreditar a priori na maior credibilidade de um documento escrito sobre um relato oral:

\begin{abstract}
A escola documental enfrenta uma alteração de seus próprios fundamentos, pois o próprio documento vem tendo mudanças em sua função social de duas maneiras. Primeiro, as comunicações mais importantes entre as pessoas não se fazem mais por meio de documentos (se é que algum dia se fizeram), mas sim oralmente, em contato direto ou por telefone. Em segundo lugar, os registros perderam sua inocência (se é que algum dia tiveram); sabe-se, agora, que eles têm um valor potencial como propaganda futura. (THOMPSON, 1992, p. 82)
\end{abstract}

Em relação a nosso projeto, optou-se pela realização das entrevistas após a leitura do material documental disponível sobre o período e o caso específico, não por considerar este necessariamente mais confiável, mas de modo a levantar pontos de contato e de contraste que pudessem ser posteriormente abordados.

Ainda que trabalhos anteriores tenham avançado consideravelmente na reconstituição da narrativa da morte de Víctor Jara, algumas questões persistem com explicações parciais. A cronologia dos acontecimentos no Estádio Chile, como a de Peña (2003), nunca ficou bem estabelecida em nenhuma reportagem. Episódios destacados em um texto 
muitas vezes não apareciam em outro, embora pudessem ser complementares, gerando uma série de fragmentos e pontos de sombra: assim como cada testemunho contém sua própria "verdade", a partir de um ponto de vista individual, as muitas reportagens escritas desde então descreveram ou ignoraram determinados acontecimentos conforme as fontes escolhidas.

Em trabalhos como o de Kósichev (1990) fica marcado o isolamento de Víctor Jara nos primeiros dias, mantido praticamente sozinho em um dos corredores do ginásio, enquanto nos depoimentos compilados por Jurado e Morales (2003) esse ponto quase não é mencionado, mas as ações de Jara nas arquibancadas - já à vista de outros presos - recebem um destaque muito maior. Joan Jara (1998), por sua vez, traz uma visão mais geral dos acontecimentos, mas sem se aprofundar em nenhum - em função da época em que publicou seu texto, quando a ditadura permanecia vigente, não chega a identificar o nome de nenhum dos companheiros de cárcere. Notamos, assim, a necessidade de um estudo preliminar da bibliografia existente para que nossas entrevistas não se tornassem apenas "mais do mesmo", mas também um trabalho de checagem dos dados contraditórios levantados em textos anteriores.

Durante a pesquisa de campo, realizada entre julho e setembro de 2012, tivemos acesso aos acervos da FVJ e pudemos levantar cerca de 40 relatos orais transcritos sobre episódios da vida e dos momentos finais do folclorista. Arquivados de forma pouco complexa, os depoimentos estavam catalogados seguindo uma numeração simples, sem ordem aparente, trazendo a identificação do nome da testemunha e - quase sempre - do ano em que o relato foi concedido. Boa parte desse material corresponde a entrevistas realizadas por Joan Jara no início dos anos 1980, quando retornou ao Chile clandestinamente para coletar material e escrever a biografia de Víctor Jara. Contudo, muitos detalhes contidos nesses documentos não foram aproveitados por Joan, que preferiu valorizar suas memórias pessoais. Desta maneira, grande parte daqueles relatos permanece inédita e seus detalhes são pouco conhecidos ainda hoje.

Entre os documentos inéditos que se destacaram está o Testimonio 2 (Héctor Herrera), concedido por um funcionário do necrotério de Santiago, responsável por reconhecer o corpo de Jara e evitar que o cantor se tornasse um desaparecido político, já que decidiu procurar o endereço de Joan e informá-la do falecimento antes que o corpo fosse levado a uma vala comum. O corpo chegou ao necrotério horas depois de ter sido desovado em Lo Espejo. Herrera foi entrevistado por Jurado e Morales (2003, p. 179-185), mas o testemunho arquivado na FVJ - e não citado por Joan - traz detalhes novos sobre a maneira como o corpo foi identificado e sua estratégia para avisar a viúva sem se tornar, ele próprio, visado pelo regime. No Testimonio 13 (Testigos Lo Espejo), há uma entrevista 
realizada por Joan com diferentes moradores da comuna onde o corpo foi encontrado. Eles revelam fatos que não foram citados em nenhuma outra obra: por exemplo, que uma das formas para ter certeza se o corpo desfigurado era mesmo de Víctor Jara foi apertar seus dedos à procura dos calos típicos de quem está habituado a tocar violão. Quanto aos testemunhos ouvidos sobre os acontecimentos do interior do Estádio Chile, o destaque é para a ausência: nenhum dos relatos endossava que Jara chegou a cantar no ginásio, muito menos que foi morto enquanto fazia isso. Alguns, no entanto, admitem que o folclorista tocou alguns de seus temas mais conhecidos durante o período em que os futuros presos políticos ficaram confinados na UTE, antes de serem levados ao Estádio Chile.

Diante da riqueza desses arquivos, pudemos comparar os dados inéditos encontrados neles com os de trabalhos já publicados, fazendo emergir daí novas questões para as entrevistas realizadas em uma fase posterior à leitura integral do acervo da FVJ. Conforme afirma José Carlos Meihy (2002, p. 145), referindo-se à entrevista de história oral, "quanto mais informações se tem previamente, mais interessantes e profundas suas questões podem ser". Deste modo, partimos para as entrevistas com algumas perguntas que ainda não haviam sido explicitamente respondidas: como as narrativas eram cronológicas se todos os relatos convergiam afirmando que os presos não tinham noção do tempo? De que maneira Víctor Jara saiu do corredor isolado e passou às arquibancadas? Quando foi a última vez que ele foi visto, efetivamente? Seguindo as recomendações de Thompson (1992, p. 258-261), fugimos do questionário fechado e optamos por uma mescla de questões abertas e outras mais dirigidas, que permitissem a fluência do diálogo e da narrativa de acordo com a preferência dos informantes, mas sanando as dúvidas ainda existentes.

Em função das limitações de tempo e recursos para a realização simultânea de entrevistas e a consulta de material documental durante a pesquisa de campo no Chile, coletamos depoimentos de indivíduos que, sabia-se de antemão, teriam condições de revelar detalhes centrais para a narrativa, em função das características de seus relatos em entrevistas concedidas a outros autores. A pesquisa não se valeu de entrevistas com militares porque os antigos oficiais procurados pela imprensa chilena limitam-se a negar que estiveram no Estádio Chile, e os soldados denunciantes seguiam as orientações de seus advogados e apenas repetiam para a imprensa os depoimentos já concedidos à Justiça, de maneira que preferimos citar estas versões, compiladas primeiro na reportagem de Jacmel Cuevas (2009). Os relatos dos soldados foram responsáveis pela alteração de pelo menos um aspecto das narrativas sobre a morte de Víctor Jara: de acordo com eles, os 44 orifícios de bala identificados pela autópsia do corpo do cantor não foram a verdadeira causa da morte - esses tiros vieram depois, para mascarar um sádico jogo de roleta russa feito pelos oficiais com uma pistola encostada na cabeça de Jara, dentro dos vestiários do Estádio Chile. 
Para a realização de nossas entrevistas, então, contamos com um universo de nove fontes, cinco das quais estiveram presas no Estádio Chile: Augusto Samaniego, professor da antiga UTE, que passou a noite de 11 de setembro com Víctor Jara e depois voltou a se encontrar com ele nos porões do ginásio; César Fernández, também professor da UTE, que se encontrou com Jara nas arquibancadas do ginásio; Boris Navia, advogado e funcionário da administração da UTE, que também teve contato com Jara nas arquibancadas, e de quem o músico pediu emprestada a caderneta para escrever aquele que seria seu último poema; Hugo González, operário detido por violar o toque de recolher, considerado de "menor periculosidade" por não ser um prisioneiro político (embora fosse militante comunista), que pôde sair do ginásio quando Jara ainda estava vivo e telefonar para Joan; ${ }^{9}$ Jorge Montealegre, que só passou pelo Estádio Chile em 1974, no segundo período de utilização do recinto, que não chegou a ter contato direto com o folclorista no cárcere, mas poderia dar o depoimento sobre como o local era encarado pelos novos prisioneiros em função dos acontecimentos recentes. Além destes, também entrevistamos Eduardo Carrasco (músico do Quilapayún), Jorge Coulon (músico do Inti-Illimani), Eugenia Arrieta, amiga de Víctor, e Joan Jara, viúva do cantor, a qual, além de contribuir com sua memória sobre os acontecimentos, aprofundou informações sobre o processo de elaboração de seu livro.

A opção por fontes "consagradas" não limitou os testemunhos à mera repetição de versões já plenamente descritas em trabalhos anteriores. A compilação da bibliografia existente e dos relatos inéditos permitiu identificar as lacunas deixadas por essa produção pregressa, bem como levantar questões novas. Essa complementaridade das entrevistas com o levantamento bibliográfico pode ser mais bem demonstrada por um caso ilustrativo de como operamos na reconstituição dos acontecimentos para produzir nossa reportagem. No Testimonio 13, por exemplo, os moradores de Lo Espejo mencionam que um homem da comunidade tirou a aliança de casamento do corpo de Víctor Jara para devolver à viúva quando a encontrasse. Esse pequeno detalhe, não levantado em nenhuma reportagem anterior, permitiu que perguntássemos a Joan Jara sobre a veracidade do relato e seu possível desfecho. A existência da versão foi confirmada, mas a aliança nunca chegou a suas mãos para confirmar se o que lhe contaram em Lo Espejo era procedente:

P: Nessa entrevista [Testimonio 13] é mencionado que alguém teria pegado o anel de matrimônio de Víctor para entregar à senhora depois...

9 Este episódio é citado no livro de Joan Jara, mas o nome de Hugo González não vem à tona, pois este jamais se identificou no telefonema. Ele pôde ser encontrado graças ao Testimonio 17 (Hugo González), arquivado na FVJ, em que descreve sua versão do acontecido. Joan e Hugo só se encontrariam pessoalmente nos anos 2000. 
R: Isso nunca chegou às minhas mãos. Nunca.

P: Tampouco se sabe quem poderia ter pegado?

R: Não, não. Não sei. Porque alguém mencionou que era como um anel, de tipo grosso, mas se tu vias a mão de Víctor... tínhamos... eu tenho ainda [esse anel], mas não posso usar mais porque é muito grande, era largo, assim. Mas qualquer pessoa, ou seja, quando Víctor tocava o violão, qualquer um podia ver o anel, e eu nunca soube se era mentira ou verdade [que alguém o pegou]. Porque na realidade o que se diz é que, entrando no Estádio Chile, os milicos os faziam tirar o relógio, as alianças e tudo [...]. Então, para mim, é difícil pensar que [depois de morto] ele ainda tivesse um anel. Não sei, não sei se era verdade ou não. ${ }^{10}$

No entanto, na versão final da reportagem, decidimos utilizar a versão dos habitantes de Lo Espejo na narrativa principal. Esta escolha não foi arbitrária. Diferentemente do que acreditava Joan Jara, nem todos os prisioneiros foram privados de seus pertences: as entrevistas que pudemos realizar com os antigos detentos haviam determinado que muitos deles conseguiram, sim, manter relógios, anéis e outros pequenos objetos na entrada do Estádio Chile. Apesar de Víctor Jara ser um prisioneiro visado pelos militares, é possível acreditar que mesmo ele tenha permanecido com seu anel até o fim. Isto porque, tanto na bibliografia existente quanto nas versões realizadas, a afirmação é que o cantor foi apartado dos demais ainda na fila de entrada ao ginásio.

Se as entrevistas permitiram abrir esta hipótese de que Jara conservou sua aliança, a consulta à bibliografia existente e o conhecimento da evolução das narrativas sobre o caso permitiram conferir ainda mais crédito à versão dos moradores de Lo Espejo. A entrevista contida no Testimonio 13 data do início dos anos 1980, uma época em que a versão majoritariamente difundida afirmava que Víctor Jara teve as mãos cortadas antes de morrer. Em um momento em que poucos além de Joan - que havia visto o corpo - sabiam que isso não correspondia à realidade, os habitantes de Lo Espejo faziam referência clara às mãos de Víctor Jara e à sua aliança de casamento, algo improvável se não as tivessem visto.

Esta escolha resume exemplarmente o processo de sobreposição e contrastes que, ao longo de toda a apuração e escrita da reportagem, fomos atingindo com as informações obtidas nos materiais documentais e nas entrevistas realizadas.

$10 \mathrm{P}=$ pergunta e $\mathrm{R}=$ resposta. Depoimento de Joan Jara. Santiago de Chile, 30 ago. 2012. Tradução própria. Citado em Maurício Brum (2013, p. 274). 


\section{Considerações finais: dos avanços narrativos possibilitados pelo testemunho oral}

O contato com a bibliografia existente, bem como os testemunhos inéditos, aflorou uma série de novas questões além daquelas previstas inicialmente, todas elas de igual pertinência para a elaboração de uma possível reconstituição fidedigna dos fatos ocorridos no ginásio. Tais pontos seriam insolúveis sem que tivéssemos nos valido da história oral, uma vez que haviam sido ignorados ou desprezados anteriormente. Um aspecto notável desse "esquecimento" diz respeito à cronologia dos fatos: algumas reportagens anteriores tentaram estabelecer uma ordem para os acontecimentos, sem, no entanto, debruçar-se sobre a dúvida básica de como isso seria possível se os prisioneiros haviam perdido a noção do tempo.

Repetidamente, os ex-prisioneiros com quem conversamos faziam comentários ligeiros sobre o dia ou turno provável em que cada acontecimento se deu, e isso ficou ainda mais explícito no relato de Boris Navia. Uma das fontes mais ouvidas em trabalhos semelhantes ao nosso, o advogado pode já ter se convertido em uma espécie de "porta-voz" (VOLDMAN, 2006) dos acontecimentos da prisão, tanto diante da imprensa quanto nas denúncias perante a Justiça do Chile. Seu relato, assim, era o que possuía maior rigor narrativo - mas de onde provinha a precisão temporal?

Todas as reportagens escritas sobre o assunto, bem como os testemunhos a que tivemos acesso e as entrevistas que realizamos, proporcionavam extrema dificuldade em saber os turnos do dia, pois os militares mantinham os refletores do ginásio ligados durante o dia e a noite. Questionado por nós sobre isso, Boris Navia então respondeu:

Os refletores eram tão potentes, havia refletores na parte superior do Estádio Chile, uns refletores muito potentes que não eram apagados nem de dia, nem de noite. Portanto, tu tens razão, ou seja, se nós não tivéssemos tido relógios, não saberíamos se estávamos de dia ou de noite. Ou seja, nos orientávamos de duas maneiras: com o relógio, e através das portas de entrada do Estádio Chile, que dão para a Alameda, porque nos vãos das portas também se podia apreciar a luz do dia ou a escuridão da noite. Ou seja, de alguma maneira sabíamos, através do relógio... Muitos tiveram os relógios confiscados, mas muitos outros conservaram o seu. E através dessas duas vias podíamos saber se estávamos de dia ou de noite. ${ }^{11}$

11 Depoimento de Boris Navia. Santiago de Chile, 28 ago. 2012. Tradução própria. Citado em Maurício Brum (2013, p. 272). 
A informação dos relógios mantidos no pulso de alguns cativos é um exemplo de como a história oral, somada à pesquisa prévia, pôde levar a um dado novo em nossa pesquisa, mesmo diante de um informante que poderia ser considerado uma fonte "esgotada", como Boris Navia. Essa mesma informação, a respeito da manutenção dos relógios e pertences pessoais, confirmada também por outros entrevistados, permitiu esclarecer dúvidas como a da aliança de casamento de Víctor Jara, descrita anteriormente. Sem o contraste do material existente não seria possível perceber a flagrante ausência de uma informação do tipo e, por outro lado, sem a entrevista, seria impossível elucidar aspectos como este.

Para usar as palavras do professor César Fernández nas memórias que compartilhou conosco, a bravura que Víctor Jara teve durante seus últimos momentos de vida é a causa mais provável para as narrativas romanceadas que se formaram em torno da sua imagem e de suas atitudes no cárcere. Jara, segundo a maioria dos relatos, sempre buscou animar os companheiros de prisão, mesmo sendo ele próprio o mais golpeado pelos militares: "Creio que essa versão, de que ele cantou e desafiou os militares, vem dessa valentia: nunca conseguiram humilhá-lo. Penso que foi isso que ocorreu. Então as pessoas começam a florear a história - flores que não são necessárias". ${ }^{12}$

Se o passado é continuamente reescrito e reinterpretado e deparamos com novas questões, por outro lado, a pesquisa documental prévia e as entrevistas realizadas em Santiago do Chile permitiram determinar que as mais conhecidas construções simbólicas dos atos de Víctor Jara não correspondiam à memória dos prisioneiros. Isto é, nenhuma fonte confirmou que o cantor tivera suas mãos ou dedos cortados - um ponto pacífico desde que a própria Joan Jara negou isso em seu livro -, tampouco que ele chegou a cantar enquanto esteve preso. De fato, com exceção dos primeiros relatos atribuídos a Miguel Cabezas e reverberados direta ou indiretamente em mais de uma publicação dos anos 1970, a tônica dos testemunhos orais e transcritos que coletamos converge: nenhum verso foi ouvido da boca de Jara no interior do Estádio Chile.

\section{Referências}

ALONSO, C. Levantate y Mirate las Manos: testimonio de una exiliada chilena en Holanda, sobre la muerte de Víctor Jara. La Bicicleta, Santiago de Chile, n. 59, p. 38-40 6 nov. 1984.

BARRAZA, F. La Nueva Canción Chilena. Santiago de Chile: Quimantú, 1972. Disponível em: <http:// www.abacq.net/imagineria/ncch2.htm>. Acesso em: 15 jun. 2013.

12 Depoimento de César Fernández. Santiago de Chile, 10 ago. 2012. Tradução própria. Citado em Maurício Brum (2013, p. 238). 
BLOCH, M. Apologia da História. Rio de Janeiro: Zahar, 2001.

BRUM, M. De la sangre, un fusil: a reconstituição da morte de Víctor Jara em livro-reportagem. Santa Maria: Universidade Federal de Santa Maria, 2013. Projeto experimental (Graduação em Comunicação Social - Jornalismo).

BRUM, M. Estádio Chile, 1973: Morte e vida de Víctor Jara, a voz da Revolução Chilena. Ijuí: Unijuí, 2014.

CANNABRAVA FILHO, P. No Olho do Furacão: América Latina nos anos 60/70. São Paulo: Cortez, 2003.

CUEVAS, J. Los estremecedores testimonios de cómo y quiénes asesinaron a Víctor Jara. Centro de Investigación Periodística, 26 mai. 2009. Disponível em < http://ciperchile.cl/2009/05/26/los-estremecedores-testimonios-de-como-y-quienes-asesinaron-a-victor-jara/> Acesso em: 24 jul. 2012.

EL DERECHO de Vivir en Paz. Direção: Carmen Luz Parot. Santiago de Chile: 1999. 101 min. Disponível em <https://www.youtube.com/watch?v=a64W_N5MgLU> Acesso em: 30 jul. 2012.

JARA, J. Canção inacabada: a vida e a obra de Víctor Jara. Rio de Janeiro: Record, 1998.

JURADO, O.; MORALES, J. M. Victor Jara: te recuerda Chile. Tafalla: Txalaparta, 2003.

KÓSICHEV, L. La guitarra y el poncho de Víctor Jara. Moscou: Progreso, 1990.

LA SEGUNDA. Santiago de Chile: El Mercurio S. A. P. 21 set. 1973. p. 24.

LETRIA, J. J. O canto arma de Víctor Jara. Lisboa: República, 1974.

LIMA, E. P. Páginas ampliadas. O livro-reportagem como extensão do jornalismo e da literatura. 3. ed. Barueri: Manole, 2004.

LOWENFELS, W. (Ed.). For Neruda, For Chile. Boston: Beacon Press, 1975.

MEIHY, J. C. S. B. Manual de história oral. 4. ed. São Paulo: Loyola, 2002.

PEÑA, Cristóbal. La sangre de un poeta. Rolling Stone, 2003. Disponível em: <http://www.rollingstone. com.ar/586871>. Acesso em: 7 mar. 2012.

SAN FRANCISCO, A. et al. Hacia una arqueología del Estadio Víctor Jara: campo de detención y tortura masiva de la dictadura en Chile (1973-1974). Revista de Arqueología Histórica Argentina y Latinoamericana, Buenos Aires, n. 4, p. 91-116, 2010.

SHERWOOD, H. C. A Entrevista Jornalística. São Paulo: Mosaico, 1981.

SIMÕES, S. S. Canto que há sido valiente siempre será canción nueva: o cancioneiro de Víctor Jara e o Golpe Civil-Militar no Chile. Dissertação (Mestrado em História). Porto Alegre: UFRGS, 2011.

TAUFIC, C. Chile en la Hoguera: Crónica de la represión militar. Buenos Aires: Corregidor, 1974.

THOMPSON, P. A voz do passado: história oral. Rio de Janeiro: Paz e Terra, 1992.

VOLDMAN, D. Definições e usos. In: FERREIRA, Marieta de Moraes; AMADO, Janaína. Usos e Abusos da História Oral. 8.ed. Rio de Janeiro: FGV, 2006. p. 33-41. 